\title{
Undiagnosed Hypothyroidism in Obstructive Sleep Apnea Syndrome
}

\section{Obstrüktif Uyku Apne Sendromunda Subklinik Hipotiroidizm}

\author{
Elif Torun Parmaksız, Banu Salepçi, Gülşen Saraç, Nesrin Kıral, Ali Fidan, Sevda Cömert, Benan Çağlayan \\ Dr. Lütfi Kırdar Kartal Training Hospital, Clinic of Pulmonary Diseases, Istanbul, Turkey
}

\section{Summary}

Objective: Lethargy, apathy, daytime sleepiness are common features of Obstructive sleep apnea syndrome (OSAS). These features are already seen in hypothyroidism. OSAS is more frequent in obese patients and overt hypothyroidism may substantially add to this risk. We aimed to evaluate the incidence of hypothyroidism in cases applying with OSAS symptoms who have no known clinical thyroid disease to evaluate the necessity of thyroid hormone screening in OSAS.

Materials and Methods: The study population consisted of patients with no known history of thyroid disease. All patients were screened in the sleep laboratory for one night and polysomnography. Serum thyroidstimulating hormone (TSH) levels were measured by chemiluminescence method in patients referred to our sleep center for an overnight sleep study.

Results: Of 1473 subjects, 1406 (95.5\%) were diagnosed as OSA (Apnea-hypopnea index $(\mathrm{AHI})>5$ ). Elevated TSH levels were detected in 3 cases in the nonapneic group (4.47\%) and 54 cases in the OSAS group (3.90\%). In mild-moderate OSAS group, the mean TSH value was 2.02 $\mu \mathrm{U} / \mathrm{ml}$ and in patients with severe OSAS this value was $2.44 \mu \mathrm{U} / \mathrm{ml}$, though the difference was not statistically significant $(p=0.08)$. AHI was found to be weakly correlated with TSH values, though the correlation was statistically significant $(r=0.05, p=0.04)$. Mean TSH values were not correlated with oxygen desaturation index (ODI) or lowest oxygen saturation values ( $\mathrm{r}=0.02$ and $\mathrm{r}=-0.02$, respectively).

Conclusion: The measurement of TSH levels in suspected OSAS cases may help both differential diagnosis between OSAS and hypothyroidism, but subclinical hypothyroidism was not found more common in patients with OSAS. (JTSM 2015;1:11-4)

Key Words: Obstructive sleep apnea syndrome, subclinical hypothyroidism, thyroid-stimulating hormone

Conflicts of Interest: The authors reported no conflict of interest related to this article.
Özet

Amaç: Halsizlik, apati ve gündüz aşırı uykululuk hali Obstrüktif uyku apne sendromunda (OUAS) sık olarak görülen bulgulardır. Bu bulgular aynı zamanda hipotiroidizmde de görülmektedir. OUAS obez hastalarda ve klinik olarak hipotiroidizm tanısı alan hastalarda daha sık görülmektedir. Bu çalışmada, OUAS şikayetleri ile başvuran ve klinik olarak bilinen hipotiroidizm tanısı olmayan hastalarda subklinik hipotiroidizmin ve OUAS'da tiroid hormone tarama gerekliliğinin araştırılması amaçlanmıştır.

Gereç ve Yöntem: Çalışmamızda, bilinen hipotiroidizm tanısı olmayan hastalar incelenmiştir. Tüm hastalar bir gece uyku laboratuvarında kalarak polisomnografi tetkiki ile değerlendirilmiştir. Tüm hastalarda Serum tiroid-uyarıcı hormon (TSH) düzeyleri ölçülmüştür.

Bulgular: Toplam 1473 kişiden 1406'sında (\%95,5) OUAS tanısı konuldu (Apne-hipopne indeksi $(\mathrm{AHI})>5$ ). Artmış TSH düzeyleri apnesi olmayan grupta sadece 3 kişide saptandı $(\% 4,47)$, OUAS grubunda ise 54 hastada saptandı $(\% 3,90)$. Hafif-orta OUAS grubunda ortalama TSH düzeyleri $2,02 \mu \mathrm{U} / \mathrm{ml}$ iken ağır OUAS hastalarında $2,44 \mu \mathrm{U} / \mathrm{ml}$ olarak saptandı; aradaki fark istatistiksel olarak anlamlı bulunmadı $(p=0,08)$. AHI ile TSH düzeyleri arasında anlamlı olmamakla birlikte hafif positive bir korelasyon saptandı $(r=0,05, p=0,04)$. Ortalama TSH düzeyleri oksijen desatürasyon indeksi veya en düşük oksijen satürasyonu ile anlamlı ilişkili bulunmadı (sırasıyla, r=0,02, r=-0,02).

Sonuç: OUAS tanısı olan hastalarda TSH düzeylerinin ölçümü OUAS ve hipotiroidizm tanısındaki ortak şikayetlerin ayırıcı tanısında yardımcıdır. Ancak subklinik hipotiroidizm OUAS hastalarında daha yüksek bulunmamıştır. (JTSM 2015;1:11-4)

Anahtar Kelimeler: Obstrüktif uyku apne sendromu, subklinik hipotiroidizm, tiroid-uyarıcı hormon

Çıkar Çatışması: Yazarlar bu makale ile ilgili olarak herhangi bir çıkar çatışması bildirmemiştir. 


\section{Introduction}

Obstructive sleep apnea is a prevalant condition that is characterized by loud snoring, arousals, sleep fragmentation and sleep-related intermittent hypoxemia. It is associated with significant mortality and morbidity. Lethargy, apathy, daytime sleepiness are common features of obstructive sleep apnea syndrome (OSAS). These features are already seen in hypothyroidism. OSAS is more frequent in obese patients and overt hypothyroidism may substantially add to this risk. A link between OSAS and hypothyroidism has been suggested due to increased frequency of either disease in the presence of the other, as well as a possible causal relationship. Recently, there is increasing interest in association of OSAS and several endocrine disorders. While obesity causes sleep apnea, sleep apnea may further exacerbate metabolic disturbances, such as insulin resistance, diabetes, dyslipidemia (1). The role of OSAS as a risk factor for hypothyroidism is less clear. There are contradictory the need of thyroid hormone screening in OSAS (2-6).

We aimed to evaluate the incidence of hypothyroidism in cases applying with OSAS symptoms who have no known clinical thyroid disease to evaluate the necessity of thyroid hormone screening in OSAS. We also aimed to compare sleep characteristics in normo- and hypothyroid cases. We examined a large population of consecutive cases undergoing polysomnography for the presence of OSAS and performed thyroid evaluation to find out accompanying hypothyroidism.

\section{Materials and Methods}

The study population consisted of patients with no known history of thyroid disease. The cases had symptoms such as snoring, witnessed apnea, excessive daytime sleepiness and unsatisfactory sleep. A thorough medical assessment, including sleep history, comorbidities, physical examination, routine laboratory tests (complete blood count and biochemical tests), thyroid function tests, electrocardiography, pulmonary function tests and chest radiographs, was completed for each subject. All patients were screened in the sleep laboratory for one night and polysomnography was employed with Viasys Sleep Screen, Viasys Cephalo, Comet apparatus and Sleep Matrix, Somno Star, Grass programmes. Throughout the night electroencephalography (EEG), electrooculography (EOG), electrocardiography (ECG), chin and tibial electromyography (EMG), respiration, snoring, body position and oxygen saturation were monitored. The digitized polysomnography recordings were scored in 30-second epochs according to standardized criteria (7). Apnea-hypopnea index (AHI) was calculated as the sum of apneas and hypopneas during the sleep period divided by total sleep time. Apneas were scored when flow signal amplitudes dropped to $\leq 10 \%$ of the stable baseline. Hypopneas were scored when a clearly discernible reduction of the flow signal was terminated by an abrupt recovery and associated with a $4 \%$ desaturation. Arousals were scored when clearly discernible reduction of the flow signal or flow-limitation was seen and terminated by abrupt recovery associated with EEG arousal in the absence of $4 \%$ desaturation. Arousal index was calculated as number of arousals per hour of sleep.

Serum thyroid-stimulating hormone (TSH) levels were measured by chemiluminescence method in patients referred to our sleep center for an overnight sleep study. These measurements were done on the same day with polysomnography. TSH values were considered normal when measured between 0.34-5.6 $\mu \mathrm{U} / \mathrm{ml}$ and elevated when measured above this limit.

Statistical analyses were performed using SPSS 17.0 package program. $P$ value less than 0.05 was considered to be significant.

\section{Results}

Between January 2005-September 2011, 1473 subjects were recruited in our sleep laboratory. Of those, 1406 (95.5\%) were diagnosed as OSA (AHI>5). Mild OSAS was diagnosed in $399(27.1 \%)$ cases, moderate OSAS was diagnosed in 346 $(23.5 \%)$ cases and severe OSAS was found in 661 (44.9\%) cases. The mean age was $49.15 \pm 11.21$ years (11-84 years). This population consisted of 977 (66.3\%) male and 496 (33.7\%) female subjects. The sleep examination data in different stages of OSAS are shown in Table 1.

Elevated TSH levels were detected in 3 cases in the nonapneic group (4.47\%) and 54 cases in the OSAS group (3.90\%). Mean TSH value was $1.76 \mu \mathrm{U} / \mathrm{ml}$ in non-apneics and $2.22 \mu \mathrm{U} /$ $\mathrm{ml}$ in apneics $(p=0.4)$. When patients with OSAS are further subgrouped, in mild-moderate OSAS group, the mean TSH value was $2.02 \mu \mathrm{U} / \mathrm{ml}$ and in patients with severe OSAS this value was $2.44 \mu \mathrm{U} / \mathrm{ml}$, though the difference was not statistically significant $(p=0.08)$. AHI was found to be weakly correlated with TSH values, though the correlation was statistically significant $(r=0.05, p=0.04)$. Mean TSH values were not correlated with oxygen desaturation index (ODI) or lowest oxygen saturation values ( $r=0.02$ and $r=-0.02$, respectively). Of patients with elevated TSH values, $98.4 \%$ had OSAS; while among the TSH normal group, OSAS frequency was $94.9 \%$. Body mass index (BMI) was not correlated with TSH levels $(r=0.03, p=0.31)$.

Arousal index was not correlated with TSH levels $(r=-0.009$, $\mathrm{p}=0.75$ ). Sleep efficiency, sleep latency, rapid eye movement (REM) latency, percentage of the sleep stages in normo- and hypo-thyroidics were compared (Table 2). Sleep efficiency was significantly lower in the patients with elevated TSH levels. REM and sleep latency seemed to get longer in the cases with hypothyroidism; however the difference was not statistically significant. The percentages of the sleep stages were similar in two groups. TSH levels were weakly negatively correlated with sleep efficiency $(r=-0.1, p<0.0001)$ and weakly positively correlated with sleep latency $(r=0.06, p=0.02)$. The correlation was statistically significant. The length of sleep stages was not significantly correlated with TSH levels.

\section{Discussion}

Our primary endpoint was to find the answer to the question of what percentage of individuals suspected of having OSAS have coexisting hypothyroidism. Thyroid function tests are frequently performed in patients with sleep apnea because of a suspected causal relationship between hypothyroidism and obstructive sleep apnea. There is also an increased prevalence of OSAS in patients with hypothyroidism $(3,8)$. Thyroid hormone replacement therapy seems to improve OSAS symptoms $(2,9,10)$. Likewise, treatment of OSAS with continuous positive airway pressure produces TSH reduction (11). All these suggest a link between OSAS and hypothyroidism. 
It is well-known that hypothyroidism is associated with hypoventilation. The ventilatory responses to hypoxemia and hypercapnia decrease in hypothyroidism and thus it worsens underlying OSAS. The low respiratory drive is the most probable reason for increased risk of OSAS in hypothyroidism. Upper airway collapse and extravasation of albumin and mucopolysaccharides in the tissues of the upper airway due to hypothyroidism and central obesity are other contributing factors. The inspiratory and expiratory muscle strength is inversely correlated with TSH levels. Nevertheless, the exact mechanism of increased TSH concentrations in OSAS still unclear $(12,13)$.

OSAS and hypothyroidism have several clinical features in common, including obesity, fatigue, daytime hypersomnolence, lethargy and apathy. The overlap in clinical presentation and the fact that sleep-related breathing disorders can accompany hypothyroidism, create a significant risk of misdiagnosis of sleep apnea among patients referred to sleep clinic who have undiagnosed hypothyroidism. Similar TSH values in patients suspected of having OSAS in our study may be contributed to this clinical resemblance. The association between these two entities has been evaluated in several previous studies. However, these reports are either case presentations or investigations including relatively small study populations $(3,6,8,14)$. To our knowledge, our report has the largest population studied to date.

Contrasting data are available concerning the necessity of screening for thyroid functions in OSAS patients. The prevalence of hypothyroidism has been reported to be between $1.2-3.1 \%$, which is not different from that in the general population $(3,4,6,15,16)$. In our study population, elevated TSH levels was detected in $3.9 \%$ in the OSAS group. There are studies claiming that the prevalence of hypothyroidism in OSA is no greater than in the general population and several others suggesting that thyroid function screening is required in OSAS (2-6). One limitation of the study is that number of cases in the apneic and nonapneic groups is very different.

According to our findings the TSH levels were similar in apneics and nonapneics, however, considering the whole study population it still seems to be higher compared to the general population. This may be due to the fact that hypothyroidism and OSAS share many similar symptoms and signs. Given the high prevalence of both clinical entities in the general population, their overlap may be coincidental.

With respect to the relationship between thyroid function and sleep and architecture, there are contradictory reports. Passouant

\begin{tabular}{|c|c|c|c|c|}
\hline $\mathrm{AHI}$ & $<5$ & $5-15$ & $16-30$ & $>30$ \\
\hline Number of cases & 67 & 399 & 346 & 661 \\
\hline N1, \% & $6.56 \pm 5.05$ & $7.55 \pm 6.98$ & $8.90 \pm 8.79$ & $10.36 \pm 8.51$ \\
\hline $\mathrm{N} 2, \%$ & $53.9 \pm 13.32$ & $51.59 \pm 10.31$ & $51.29 \pm 10.28$ & $65.34 \pm 18.72$ \\
\hline $\mathrm{AHI}$ & $2.46 \pm 1.52$ & $9.69 \pm 2.95$ & $21.68 \pm 4.47$ & $60.63 \pm 23.86$ \\
\hline ODI & $1.21 \pm 1.29$ & $6.01 \pm 3.78$ & $15.73 \pm 11.00$ & $52.60 \pm 25.17$ \\
\hline Lowest spO2 (\%) & $88.53 \pm 12.23$ & $85.55 \pm 6.77$ & $82.38 \pm 8.30$ & $71.97 \pm 13.13$ \\
\hline Arousal index & $16.15 \pm 12.49$ & $16.53 \pm 9.12$ & $21.51 \pm 10.55$ & $37.96 \pm 19.70$ \\
\hline
\end{tabular}

AHI: Apnea-hypopnea index, REM: rapid eye movement, ODI: oxygen desaturation index, TSH: thyroid-stimulating hormone, BMI: Body mass index. Mean \pm SD's are provided in the Table. *missing data.

Table 2. Comparison of some polysomnographic data between normo- and hypothyroidism

\begin{tabular}{|c|c|c|c|}
\hline & $\mathrm{TSH}<5.6$ & $\mathrm{TSH}>5.6$ & $p$ value \\
\hline Sleep latency (minutes) & $20.64 \pm 23.86$ & $23.32 \pm 19.07$ & 0.390 \\
\hline N1, (\%) & $8.95 \pm 7.88$ & $9.62 \pm 6.58$ & 0.520 \\
\hline N2, (\%) & $54.69 \pm 12.23$ & $52.73 \pm 12.45$ & 0.220 \\
\hline REM, (\%) & $19.98 \pm 10.52$ & $13.26 \pm 7.30$ & 0.600 \\
\hline Arousal index & $27.33 \pm 18.25$ & $24.88 \pm 15.44$ & 0.300 \\
\hline
\end{tabular}

REM: rapid eye movement, TSH: thyroid-stimulating hormone, Mean $\pm S D^{\prime} s$ are provided in the Table. 
et al. reported increased sleep latency, REM density and REM duration as well as decreased sleep time in hyperthyroidism (17). Dunleavy et al. reported increased percentage of slow wave sleep in hyperthyroidism, whereas according to Kales et al. sleep duration, latency and REM parameters were normal in patients with hypothyroidism $(18,19)$. In our population sleep efficiency tends to decrease with elevation in TSH levels. Elevated TSH levels also accompany longer REM and sleep latencies.

In a study which investigated the prevalence of thyroid disease in OSAS in Saudi Arabic population, newly diagnosed clinical hypothyroidism was seen in $0.4 \%$ of the subjects and the prevalence of newly diagnosed subclinical hypothyroidism was $11.1 \%$. In the non-apneic population, the prevalence of newly diagnosed clinical hypothyroidism was $1.4 \%$, and the prevalence of newly diagnosed subclinical hypothyroidism was $4 \%$. The authors concluded that newly diagnosed clinical hypothyroidism is infrequent in OSAS, in contrast to subclinical hypothyroidism (20). Resta et al. restricted the study population to overweight and obese subjects referred to the sleep laboratory and reported the prevalence of previously undiagnosed subclinical hypothyroidism to be $11.5 \%$. They suggested that thyroid function should be evaluated in all obese patients suffering from OSAS (21).

Sakellaropoulou et al. aimed to evaluate thyroid functions in children with OSAS and recorded hypothyroidism in $11.4 \%$ and Hashimoto's thyroiditis in $6.8 \%$ of the study population. They claimed the necessity of thyroid function screening in children for the differential diagnosis of primary sleep apnea and hypothyroid sleep-disordered breathing in order to differentiate these two conditions (5).

Thyroid function screening in patients with OSAS is not considered necessary by several authors unless the patient is symptomatic or is a member of risk group $(4,16)$. Nevertheless, considering the clinical overlap in presentation of OSAS and hypothyroidism, some authors indicate that screening for hypothyroidism is required to prevent misdiagnosis or underdiagnosis (2). The positive correlation between $\mathrm{AHI}$ and $\mathrm{TSH}$ in our study supports the fact that thyroid function test screening is neccessary.

The measurement of TSH levels in suspected OSAS cases may help both differential diagnosis between OSAS and hypothyroidism, as well as diagnosis of subclinical hypothyroidism.

\section{References}

1. Tasali E, Ip MSM. Obstructive sleep apnea and metabolic syndrome: alterations in glucose metabolism and inflammation. Proc Am Thorac Soc 2008;5:207-17.

2. Skjodt NM, Atkar R, Easton PA. Screening for hypothyroidism in sleep apnea. Am J Respir Crit Care Med 1999;160:732-5.

3. 3.Lin CC, Tsan KW, Chen PJ. The relationship between sleep apnea syndrome and hypothyroidism. Chest 1992;102:1663-7.
4. Winkelman JW, Goldman H, Piscatelli N, Lukas SE, Dorsey CM, Cunningham $S$. Are thyroid function tests necessary in patients with suspected sleep apnea? Sleep 1996;19:790-3.

5. Sakellaropoulou AV, Hatzistilianou MN, Emporiadou MN, Aivazis VT, Rousso I, Athanasiadou-Piperopoulou F. Evaluation of thyroid gland function in children with obstructive apnea hypopnea syndrome. Int J Immunopathol Pharmacol 2011;24:377-86.

6. Skjodt NM, Atkar R, Easton PA. Screening for Hypothyroidism in Sleep Apnea . Am. J. Respir. Crit. Care Med 1999;160:732-5.

7. Iber C, Ancoli-Israel S, Chesson A, Quan S. for the American Academy of Sleep Medicine. The AASM manual for the scoring of sleep and associated events: rules, terminology and technical specifications. 1st ed. Westchester, IL: American Academy of Sleep Medicine; 2007.

8. Grunstein RR, Sullivan CE. Sleep apnea and hypothyroidism: mechanisms and management. Am J Med 1988;85:775-9.

9. Jha A, Sharma SK, Tandon N, Lakshmy R, Kadhiravan T, Handa KK, Gupta R, Pandey RM, Chaturvedi PK. Thyroxine replacement therapy reverses sleep-disordered breathing in patients with primary hypothyroidism. Sleep Med 2006;7:55-61.

10. Kittle WM, Chaudhary BA. Sleep apnea and hypothyroidism. South Med J 1988;81:1421-5.

11. Meston N, Davies RJ, Mullins R, Jenkinson C, Wass JA, Stradling JR. Endocrine effects of nasal continuous positive airway pressure in male patients with obstructive sleep apnoea. I Intern Med 2003;254:447-54.

12. Lanfranco F, Motta G, Minetto MA, Baldi M, Balbo M, Ghigo E, Arvat $E$, Maccario M. Neuroendocrine alterations in obese patients with sleep apnea syndrome. Int J Endocrinol 2010;2010:474518.

13. Saaresrenta T, Polo O. Hormones and breathing. Chest 2002; 122:2:165-82.

14. Grunstein RR, Sullivan CE. Sleep apnea and hypothyroidism: mechanisms and management. Am J Med 1988;85:775-9.

15. Mickelson SA, Lian T, Rosenthal L. Thyroid testing and thyroid hormone replacement in patients with sleep disordered breathing. Ear Nose Throat J 1999;78:768-71, 774-5.

16. Kapur VK, Koepsell TD, Demaine J, Hert R, Sandblom RE, Psaty BM. Association of Hypothyroidism and Obstructive Sleep Apnea. Am I Respir Crit Care Med 1998;158:1379-83.

17. Passouant $P$, Passouant T, Cadilhac J. Linfluence de Ihyperthyroidie sur le sommeil etude clinique et experimentale. Revue Neurologique 1966;115:353-4.

18. Dunleavy DLF, Oswald I, Brown P, Strong JA. Hyperthyroidism, sleep and growth hormone. Electroencephalography and Clinical Neurophysiology 1974;36:259-63.

19. Kales A, Heuser G, Jacobson A, Kales JD, Hanley J, Zweizig JR, Paulson MJ. All night sleep studies in hypothyroid patients, before and after treatment. J Clin Endocrinol Metab 1967;27:1593-9.

20. Bahammam SA, Sharif MM, Jammah AA, Bahammam AS. Prevalence of thyroid disease in patients with obstructive sleep apnea. Respir Med 2011;105:1755-60.

21. Resta O, Pannacciulli N, Di Gioia G, Stefàno A, Barbaro MP, De Pergola G. High prevalence of previously unknown subclinical hypothyroidism in obese patients referred to a sleep clinic for sleep disordered breathing. Nutr Metab Cardiovasc Dis 2004;14:248-53. 